sciendoZagreb International Review of Economics \& Business, Vol. 22, Special Conference Issue, pp. 95-106, 2019 (C) 2019 Faculty of Economics and Business, University of Zagreb and De Gruyter Open

All rights reserved. Printed in Croatia

ISSN 1331-5609; UDC: $33+65$

DOI: 10.2478 /zireb-2019-0007

CONFERENCE PAPER

\title{
Senior Entrepreneurship. Self-employment by Older People - an Uncharted Territory
}

\author{
Uwe Fachinger*
}

Abstract: An ageing population means a growing number of healthy older people with human capital, financial resources, and time available to contribute to economic activities. However, the economic potential of older people remains mostly underused, which leads to the question, how to make best use of the underused. One way would be fostering senior entrepreneurship. The paper discusses which factors may positively influence or hinder the self-employment of older people. Overall, attention will be drawn to the relevance of older people in the field of business and entrepreneurial economics. From an economic point of view, it seems necessary not only to focus on young people but also to take into account the large and still growing economic potential of the elderly. There seems to be a treasure in waiting.

Keywords: Senior entrepreneurship; self-employment; older people

JEL Classification: J14, J21, L26

\section{Introduction}

The aging and shrinking population in most developed countries is still seen as a major societal and economic problem (European Commission, 2015a). An ageing population means a growing number of healthy older people with human capital, financial resources, and time available to contribute to economic activities. In the literature it is pointed out that this growing part of the population can be seen as a main driver for further economic development under the catch phrase silver economy. Significant growth potential has been associated with the silver economy, based on the rise in consumer spending in this age group and increasing efforts by public and private organisations to cater for the needs of the elderly.

\footnotetext{
${ }^{*}$ Uwe Fachinger is at Institute of Gerontology, University of Vechta, Vechta, Germany.
} 
There are two other aspects regarding the economic potential of this group: Human capital and availability of time, which are much less discussed. The human capital of older people remains mostly unused despite the fact that some people are working e. g. as volunteers or senior experts. This leads to the question, how to make best use of the underused economic potential of older people.

One possible way could be the promotion of volunteering. However, this would exploit only parts of the economic potential, as volunteering is carried out by a specific part of the elderly, mainly by those belonging to the so-called middle classes. Another option would be to foster entrepreneurship of the elderly. Nevertheless, most economic policy programmes focus on the support of young entrepreneurs and start-ups (Commission of the European Communities, 2003). This results from the perception that young people are creative, innovative, and lateral thinkers. Numerous courses at universities, business schools etc. try to convince and prepare young people to take the risk of becoming self-employed and running their own businesses.

Fostering entrepreneurship of the elderly may be an even better way to tackle the societal and economic challenges of an ageing population as those people would stay in the labour force and even may generate economic growth (Kautonen, Kibler, \& Minniti, 2017; Halabisky, 2012; Lewis \& Walker, 2011). Yet little is known about the reasons, why older people become self-employed.

To develop adequate political measures for facilitating entrepreneurship or self-employment in old age, it is necessary to know whether this is a serious option for the elderly or not. Further, the main factors which support and may prevent becoming an entrepreneur in older age should be studied. Only when the main factors which explain self-employment of the elderly are identified, it is possible to develop policy measures to support older people in staying or becoming self-employed. The involvement of older people in self-employment, however, is an economic phenomenon which was mostly overlooked in the past.

\section{Background}

Developed countries face almost the same problem: There is an ageing and shrinking society which -as often stated- will lead to major economic and societal problems because of effects on the quantity and quality of the labour force (European Commission, 2015a; Liang, Wang, \& Lazear, 2014). It is assumed that the shrinking labour force will lead to lower economic growth. And that the rate of renewal of labour-force qualifications will be lower as the number of young people in the population will be low. Furthermore, there could be prejudices that an ageing population may add to minor innovations as it is thought that older people are on average not as creative or innovative as younger people (Organisation for Economic Co-operation and De- 
velopment (OECD) \& European Union, 2017; Organisation for Economic Co-operation and Development (OECD) \& The European Commission, 2015; Liang, Wang, \& Lazear, 2014).

At the same time, it is thought of rising social costs because of an increasing number of people in need. Older people on average are not as healthy as younger people. It is assumed -and many studies are giving evidence for this positive correlation- that with the process of ageing the expenditures for health care are increasing. At the same time the overall expenditures for long term care will increase, as the number of older people will rise and the probability of being in need for long term care is higher in older age groups, especially in the group of the very old people of the age 85 and above. But the highest pressure concerning the expenditures comes from the pension systems. Older people above a certain age are no longer part of the labour force and have to rely on income out of pension systems, be it statutory, occupational and/or private pensions. These people are seen as unproductive and it is assumed that their income depends on the labour market activities of the young. Therefore, the term dependency ratio is used as a measure of the economic, especially financial burden of younger generations.

However, an ageing population means also a growing population of elderly people with high economic potential. They possess high human capital and due to their age also a considerable amount of experiential knowledge. During their life course, elderly have the potential to accumulate financial resources and are on average wealthier than younger generations even without taking the entitlements to benefits of pension systems into account. Another point frequently overlooked is the time factor. Older people are no longer participating in the labour market and therefore have a lot of spare time.

Against this background, the question arises how the economy of an ageing society will develop. Considering the positive factors, analyses of the economic potential of the elderly mostly focused on the demand side of the economy. This is due to previously mentioned aspects, in particular the income and wealth situation of older people and the time for spending money and consumption. A so-called silver economy is identified and it is assumed that the spending power of the older generations is a driving force of economic development (European Commission, 2015c; Eatock, 2015; Jackson, 2014). However, the structure of consumer spending will change. Older people spend more money on health products and services as well as on leisure goods. The last product group encompasses expenditures for travel, sports and culture.

Two other aspects of the economic potential of older people are less often discussed. Their human capital and the availability of time. In economic analysis, these resources of older people are seldom taken into account. The focus of the discussion lies on the idea that people should work longer to reduce the social costs of old age pension systems. 
Nevertheless, empirical analyses show that the resources of older people often remain unused, even so some people are working e. g. as volunteers or as senior experts. So from an economic point of view, the question arises, how to make the best use of the underused economic potential of older people.

In the following, specific aspects of senior entrepreneurship will be discussed, giving a note on the terminology of seniors or older people first. There exists no general definition of older people. Economic analysis often refers to the chronological or calendar age (Minola, Criaco, \& Obschonka, 2016). In empirical analysis, older people are often those who are aged 50 or above. However, calendar age is not a determining factor or an explanatory variable, it is at best a proxy variable. Age is multi-dimensional and should be distinguished at least between biological age, psychological age, cognitive age, social age and institutional age (Settersten \& Mayer, 1997; Kohli, 1986; Binstock \& Shanas, 1985).

Regarding senior entrepreneurship, in what follows, older people are defined as those who are retired from the labour force. That means that the transition from one life stage to the next, i. e. retirement, has already taken place, but this happens not always at the same age, it differs between occupations, industrial sectors, as well as gender within and between countries.

\section{The Specifics of Older People}

When analysing senior entrepreneurship or self-employment in older age, four factors are of high relevance for describing and explaining the economic behaviour. These are income and wealth, time sovereignty, work experience and previous occupations and the institutional framework. It is argued that it is necessary to consider older people which are retired as a group or cohort in its own right (Lewis \& Walker, 2011).

With respect to income and wealth, the composition differs from the situation in earlier life stages. Normally the monthly income is lower after retirement and the accumulated wealth is higher. What is especially of relevance is that retirees normally do not have to work to earn a living. To retire means receiving benefits from statutory, occupational and/or private pension systems. Furthermore, -depending on the specific pension system- most pensions are a continuous stream of permanent income during retirement. That means that the permanent income component is higher in absolute and in relative terms as it is shown in Figure 1. As the permanent income component is higher for retired people, the financial risks of becoming self-employed and going bankrupt are lower (Weller \& Wenger, 2017). 
Figure 1: Structure of income during employment and during retirement

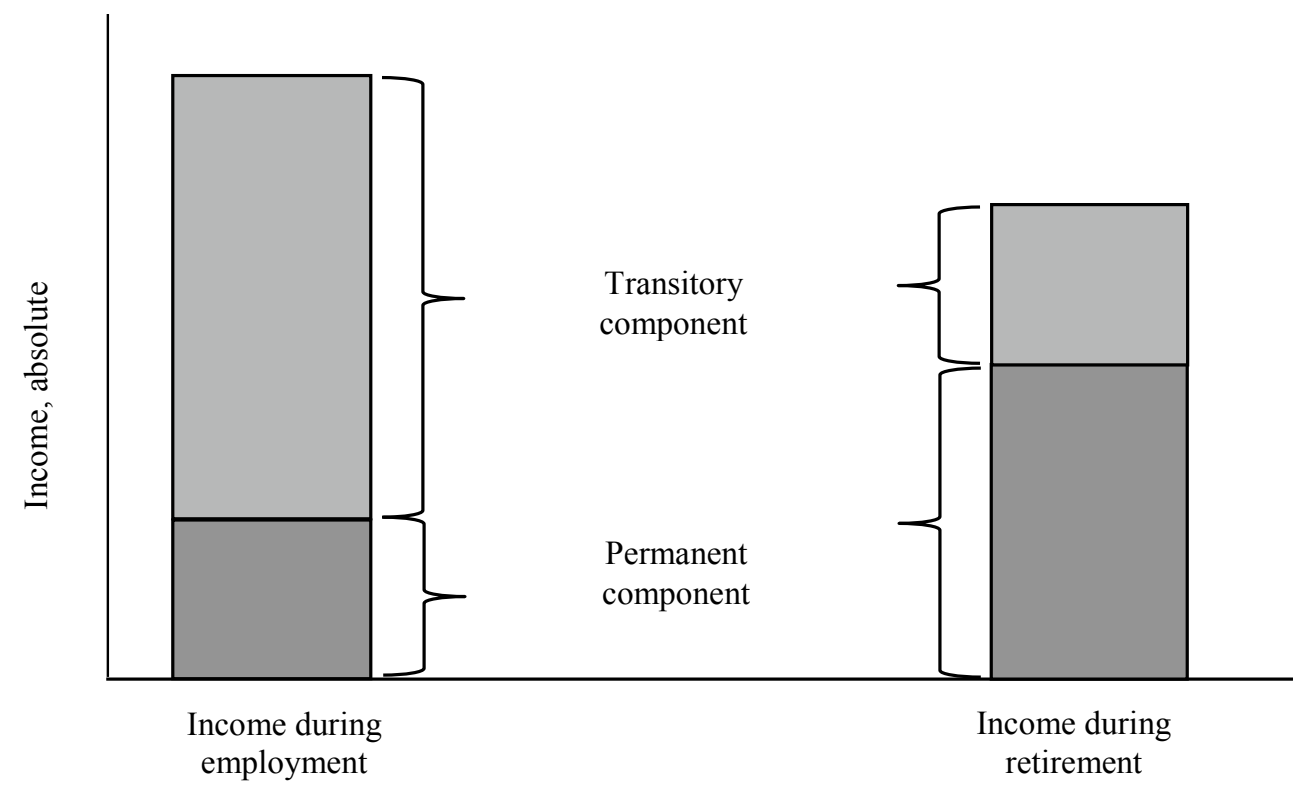

Source: Authors' own.

Regarding time sovereignty, it can be assumed, that after retiring, people's time budgets are mostly not dominated by contractual obligations. Working hours normally cease to exist and travel time to and from work places do not longer persist. Additionally, most people have entered the so-called empty nest phase of life, in which children are no longer at home and care work for own partners did not yet begin. This sets a lot of time free and from an individual point of view this free time has to be utilised. A meaningful interpretation becomes necessary of how to fill this time with activity. This could be leisure activities, working as volunteers with less obligations or as senior experts even abroad, or starting one's own business.

Work experience, previous occupations, and employment history of older people are also positive factors for senior entrepreneurship or for becoming self-employed (Solinge, 2014). When starting a business, older people may have potential prior work experience in the relevant industrial sector which provides them with important background knowledge and the x's and o's of the area in question. This may make it a lot easier to be successful in becoming self-employed. But for this the duration is very important. The longer people work, the more experienced they become in what they are doing. Additionally, the closeness to previous work is relevant. The more people have worked in the specific area, in which they would like to become self-employed, the more specific experience they have gained and the more they know about the 
details and imponderabilities. Older people can look back on previous occupations or employment history. They exhibit a work career as dependent worker and/or have experience as self-employed and sometimes they even were serial entrepreneurs. During their work careers, elderly may have developed networks which may ease the process of becoming self-employed. Network partners might support the idea of working after retiring and may help by keeping the contacts or relationships intact and may even place an order.

Another important aspect regarding self-employment by older people are the institutional framework and legal regulations (Abdesselam, Bonnet, \& Renou-Maissant, 2017, p. 9 ff.), which are mostly overlooked in economic analysis as those are typically included in the ceteris paribus assumption. Legal retirement age, for example, determines when the employment phase ends and implies the termination of dependent and -depending on the occupation- of independent work. However, such regulations are neither constant over time nor between occupational groups or industrial sectors. There exist different retirement ages for dependent workers and self-employed people. For example in Germany:

- The retirement age for employees with compulsory insurance is 67 (§ 35 SGB VI). But under specific conditions there is the possibility to retire earlier or to work longer. If the conditions are met -e.g. having been insured in the statutory pension system for at least 35 years- one can retire after reaching the age of 63 ( $\$ 36$ SGB VI) but for each month earlier the pension will be reduced by 0.3 $\%$ ( $\$ 77$ Abs. 2 Nr. 2a SGB VI). On the other hand, if people are able to work longer than the age of 67 in agreement with the employer, their pensions will increase by $0.5 \%$ per month ( 77 Abs. 2 Nr. 2b SGB VI).

- The retirement age of tenured professors (Beamtete Professoren) can vary due to the specific laws of the federal states (Bundesländer). Whereas in Berlin ${ }^{1}$, Rhineland-Palatinate ${ }^{2}$, Saarland ${ }^{3}$, and Saxony-Anhalt ${ }^{4}$, the legal retirement age is 65 , in the other Bundesländer it is 67 , i. e. Baden-Württemberg ${ }^{5}$, Bavaria $^{6}$, Brandenburg $^{7}$, Bremen $^{8}$, Hamburg $^{9}$, Hesse $^{10}$, Mecklenburg-West Pomerania $^{11}$, Lower Saxony ${ }^{12}$, North Rhine-Westphalia ${ }^{13}$, Schleswig-Holstein ${ }^{14}$, Saxony $^{15}$, or Thuringia ${ }^{16}$.

- Until 2006 the official retirement age of physicians was 70. With respect to the structural socio-demographic changes this age limit was abandoned so that physicians can now practise till they die. Such amendments of law result in cohort effects as they apply as of a certain point in time.

- Notaries have to retire at the end of the month, when they became 70 ( $\$ 48 \mathrm{a}$ Bundesnotarordnung).

All these legal regulations influence the decision and constitute age differences regarding the opportunity to become self-employed. 
Another determining factor is the income situation after retirement. There may be some income ceilings in the tax law which will generate incentives or disincentives to earn income by being self-employed or there may exist some regulations regarding tax exemptions of specific incomes. However, not only taxes but also contributions from additional income e.g. for health care and long term care insurance may have to be paid. All these financial regulations by the state and by statutory insurance systems may influence the decision to become self-employed in a positive or negative way. Beside the reduction by taxation and paying contributions, reduction of public or occupational pensions can happen due to personal allowance. If income passes a specific threshold, the pensions will be reduced for the same amount as it is the case in Germany for widow's pension.

As the discussion above shows, older people differ in some major aspects from younger people and income and wealth, work history, time sovereignty and also the institutional and legal framework have to be taken into account, when aspects of becoming self-employed are analysed.

\section{Potential for Entrepreneurial Activities}

Given the specific situation of older people, the question arises, whether they have thought about becoming self-employed before (for empirical information on senior entrepreneurship see Schøtt, Rogoff, Herrington, \& Kew, 2017; Solinge, 2014; Kautonen, 2013; Hatak, Kautonen, \& Fink, 2013; Halabisky, 2012). In the following tables, data from the Eurobarometer survey of 2012 exemplarily for Croatia, Germany and the average for all countries are shown with respect to three questions concerning the start-up of a business (European Commission, 2015b). Unfortunately, the oldest age group starts at the age of 55, in which there are people who are members of the labour force, working fulltime and people who are retired. This is -as discussed above- a problem because for these people the circumstances differ. The younger people for example may have to give up an attractive job whereas retired people can work without losing any money.

The tables show that the percentage of people who are not thinking about starting up a business is highest in the oldest age group, with almost the same numbers in Croatia and Germany, whereas the percentages in the other age groups are lower for Croatia. This indicates a higher interest in starting up a business on average. This is also reflected in the results of the two other questions. The percentages in Croatia are mostly above the averages and those for Germany are below the averages of all countries. 
Table 1: Propensity to start up a business

\begin{tabular}{|l|c|c|c|c|}
\hline & \multicolumn{4}{|c|}{ It never came to your mind to start up a business } \\
\hline & 15 to 24 & 25 to 39 & 40 to 54 & 55 and older \\
\hline HR - Croatia & 44.5 & 39.5 & 46.9 & 70.5 \\
\hline DE - Germany & 57.7 & 57.0 & 65.3 & 71.2 \\
\hline all countries & 48.3 & 44.2 & 49.7 & 65.1 \\
\hline & \multicolumn{4}{|c|}{ You are thinking about starting up a business } \\
\hline & 15 to 24 & 25 to 39 & 40 to 54 & 55 and older \\
\hline HR - Croatia & 24.3 & 26.4 & 17.0 & 4.0 \\
\hline DE - Germany & 24.2 & 17.3 & 5.0 & 3.4 \\
\hline all countries & 28.8 & 23.6 & 15.7 & 4.9 \\
\hline & \multicolumn{5}{|c|}{ Early-stage activity } & 55 and older \\
\hline & 15 to 24 & 25 to 39 & 40 to 54 & 22.6 \\
\hline HR - Croatia & 20.8 & 32.9 & 33.0 & 21.6 \\
\hline DE - Germany & 15.8 & 22.5 & 25.6 & 22.9 \\
\hline all countries & 18.3 & 27.0 & 28.8 & \\
\hline
\end{tabular}

Source: Own calculations on the basis of European Commission, 2015 b.

Overall, it seems that at least some people are interested in starting up a business in the eldest age group. This is supported by Figure 2, where the overall entrepreneurial intention by age groups is shown. It can be seen that at least $7 \%$ of the interviewees in the age group of 65 and older have such intentions and that around $4 \%$ of people from this age group have undertaken early-stage entrepreneurship activities.

Figure 2: Entrepreneurial intentions, in $\%$ of the age group

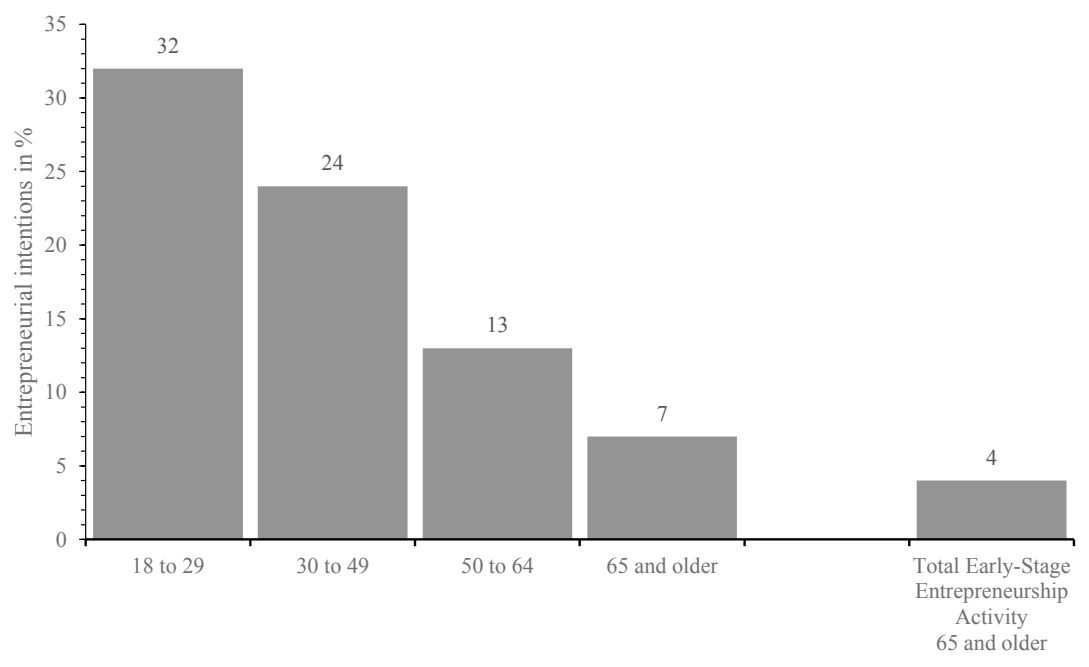

Age group

Source: Schøtt, Rogoff, Herrington, \& Kew, 2017, p. 22. 
Overlooking the few empirical information on the potential for entrepreneurial activities of seniors, it seems as if there exists a sufficiently large number of elderly who would be inclined to become self-employed.

\section{Fostering Self-employment in Old Age}

Considering the argumentation regarding the socio-demographic development, there is the political goal of fostering self-employment in old age (Kautonen, Kibler, \& Minniti, 2017; Organisation for Economic Co-operation and Development (OECD) \& The European Commission, 2015; Isele \& Rogoff, 2014, p. 144 f.; Halabisky, 2012). To develop adequate political measures, it is necessary to know as specific as possible the political intentions, the status quo and the determining factors of self-employment in old age.

With respect to the determining factors which could be targeted by political measures, there are some theoretical approaches concerning self-employment in older age, which are trying to explain why older people become self-employed: The time allocation model, the opportunity-necessity model, the early retirement, self-employment model, the contingency model and the theory of planned behaviour (Funken, 2015; Luck, Kraus, \& Bouncken, 2014; Solinge, 2014; Tornikoski \& Kautonen, 2009). But none of these approaches is dominant in the literature (for an overview see e. g. Fachinger \& Bögenhold, 2016). However, there is some agreement on the relevant determinants. One set of determinants consists of person-related opportunity costs, another set on liquidity constraints and a third one on time allocation.

To know which determinants are relevant and should be targeted by political measures, empirical analysis is necessary. A literature overview reveals, that there is no consensus about the reasons behind the self-employment of people at advanced age (Fachinger \& Bögenhold, 2016). Up to now, the results are contradictory referring to old age income, access to finance, or the health status. Some empirical analyses show a negative relationship, other came up with a positive correlation, and some analysis exist, where the effect concerning the influence on starting a business in old age is more or less unimportant.

Additionally, self-employment demonstrates life cycle effects, which is hardly considered in empirical studies (Solinge, 2014; Jayawarna, Rouse, \& Kitching, 2011). Cross-sectional data were often used for a comparison between different age groups, thereby defining the oldest group sometimes starting at 40 and older and sometimes starting at 65 and older. Results were interpreted as development over the life course, erroneously mixing age, cohort and period effects (e. g. Minola, Criaco, \& Obschonka, 2016 and the cited literature within as negative examples). 


\section{Final Remarks}

In economic literature, it is undisputed, that an increase of older people becoming self-employed will have positive economic and social effects (Kautonen, 2013). Older people constitute a reservoir of the work force with high human capital, high work experience, high permanent income and wealth, as well as availability of time. However, little is known about the entrepreneurial behaviour and the reasons to become self-employed in older ages.

Theoretical and empirical analysis can be characterised as being disparate. The differences between people being retired or not, their time sovereignty and their income security are not taken into account. Even more, in the analysis, the relevance of country-specific institutional regulations and the importance of life cycle effects are often neglected. Therefore, it is unclear what the main driving forces for becoming self-employed after retiring are. It could be out of necessity, to continue doing the same thing they have been doing previously in dependent work. The reasons for becoming self-employed may be interest and curiosity to explore new opportunities in life, to change to new uncontested terrains of activity, or a mixture of the mentioned factors.

There seems to be political intention on international (EU), national and regional level to foster senior entrepreneurship and self-employment in older age (Kautonen, Kibler, \& Minniti, 2017; Organisation for Economic Co-operation and Development (OECD) \& The European Commission, 2015; Isele \& Rogoff, 2014). However, the current political measures are more or less supporting young entrepreneurs and start-ups. Young people are seen as creative, innovative, lateral thinkers, or even contrarians, which pose a source for successful entrepreneurs. Numerous courses at universities, business schools etc. try to convince and prepare young people to take the risk of becoming self-employed and running their own businesses. These measures cannot be used for fostering older people to start a business. The learning behaviour of the elderly is different, they warrant separate educational measures which are established in geragogy, i. e. the educational theory regarding older adults.

In conclusion, fostering entrepreneurship of the elderly may be a way to tackle the problems of an ageing population. By becoming self-employed, older people stay in the labour force and generate economic growth. Overall, the relevance of older people in the field of business and entrepreneurial economics will increase. Given the ageing population from an economic point of view, it seems necessary to take into account the large and still growing economic potential of the elderly. There seems to be a treasure in waiting. 


\section{NOTES}

${ }^{1} \S 99$ LBG combined with $\S 38$ Abs. 1 LBG; $§ 38$ Abs. 2 LBG; $§ 39$ Abs. 3 Nr. 2 LBG.

$2 \S 107$ LBG combined with $\S 37$ Abs.1 LBG; § 38 LBG; § 39 Abs.1 LBG.

${ }^{3} \S 41$ Abs. 1UG combined with § 43 Abs.1 SBG; § 43 Abs. 3 SBG; § 44 Nr.1 SBG.

${ }^{4} \S 46$ Abs. 1 HSG LSA combined with $\S 39$ Abs. 1 LBG LSA; $§ 39$ Abs. 2 LBG LSA; $\$ 40$ Abs. 1 LBG LSA.

${ }^{5} \S 36$ Abs. 1 LBG combined with Art. $62 \S 3$ Abs. 2 des Dienstrechtsreformgesetzes vom 9. November 2010 (DRG); § 39 LBG i.V.m. § 45 Abs. 2 LHG; § 40 Abs. 1 Nr. 1 LBG.

${ }^{6}$ Art. 62 BayBG combined with Art. 143 Abs. 1 BayBG; Art. 63 Abs. 1, 2 BayBG; Art. 64 Nr. 1 BayBG).

${ }^{7} \S 108$ LBG combined with $\S 45$ Abs. 1 LBG; $\S 44$ Abs. 3 BbgHG, $\S 45$ Abs. 3 LBG; $\S 46$ Abs.1 LBG.

${ }^{8} \S 35$ Abs. 1, 2 BremBG; $\S 35$ Abs. 4 BremBG; $\S 36$ Abs. 1 BremBG.

${ }^{9} \S 117$ HmbBG combined with $\S 35$ Abs. 1, 2 HmbBG; $§ 16$ Abs. 7 HmbHG, § 123 HmbBG i.V.m. § 35 Abs. 4 Nr. 1 HmbBG; § 36 Abs. 1 Nr. 2 HmbBG.

${ }^{10} \S 33$ Abs. 1,3 HBG; § 34 Abs. 1,2 HBG; § 35 Nr. 2 HBG.

${ }^{11} \S 35$ Abs.1,2 LBGM-V; § 35 Abs. 3 LBGM-V; § 36 Abs.1 LBGM-V.

$12 \S 27$ Abs. 2 NHG combined with § 72 Abs.8 NHG; § 36 NBG; § 37 Abs.1 Nr.1 NBG.

${ }^{13} \S 121$ Abs. 1 LBG combined with $\S 31$ Abs. 1, 2 LBG; $\S 32$ Abs. 1, 2 LBG; $\S 33$ Abs. 3 Nr. 1 LBG.

${ }^{14} \S 35$ Abs. 1,2 LBG; § 35 Abs.4 LBG; § 36 Abs. 1 LBG.

${ }^{15} \S 140$ SächsBG combined with $§ 46$ Abs. 1, 2 SächsBG; § 59 Abs. 1 SächsHSFG i.V.m. § 47 SächsBG; § 48 Nr. 1 SächsBG.

${ }^{16} \S 120$ ThürBG combined with $\S 43$ Abs. 1, 2 ThürBG; $\S 43$ Abs. 5, 6 ThürBG; $\S 44$ Abs. 1 ThürBG.

\section{REFERENCES}

Abdesselam, R., Bonnet, J., \& Renou-Maissant, P. (2017). The demography of enterprises and employment in the european union countries. What are the drivers of business demography and employment in european countries? Working Paper. Caen: Centre de Recherche en Économie et Management / Center for Research in Economics and Management, Université de Caen Normandie.

Binstock, R. H., \& Shanas, E. (1985). Handbook of ageing and the social sciences (Vol. 2. ed). New York: Van Nostrand Reinhold.

Commission of the European Communities. (2003). Green paper. Entrepreneurship in europe. Brussels: Commission of the European Communities.

Eatock, D. (2015). The silver economy. Opportunities from ageing EPRS Briefing. Brussels: European Parliamentary Research Service (EPRS).

European Commission. (2015a). The 2015 ageing report. Economic and budgetary projections for the 28 eu member states (2013-2060). In European Commission (Ed.), European Economy. Luxembourg: Directorate-General for Economic and Financial Affairs of the European Commission.

European Commission. (2015b). Eurobarometer 77.3 (2012) TNS OPINION \& SOCIAL. Brussels: GESIS Data Archive, Cologne.

European Commission. (2015c). Growing the silver economy in europe. In European Commission (Ed.), Background Paper. Brussels. 
Fachinger, U., \& Bögenhold, D. (2016). Self-employment of older people: New chances and challenges for research Discussion Paper. Vechta: Fachgebiet Ökonomie und Demographischer Wandel, Institut für Gerontologie.

Funken, R. G., Michael. (2015). Entrepreneurship and aging. In N. A. Pachana (Ed.), Encyclopedia of geropsychology (pp. 1-7): Springer Singapore.

Halabisky, D. (2012). Entrepreneurial activities in europe - senior entrepreneurship OECD Employment Policy Papers (pp. 30). Luxembourg: Organisation for Economic Co-operation and Development, OECD Publishing.

Hatak, I., Kautonen, T., \& Fink, M. (2013). Senior-unternehmertum. Empirische evidenz aus 27 europäischen ländern. Die Betriebswirtschaft, 73(1), 7-26.

Isele, E., \& Rogoff, E. G. (2014). Senior entrepreneurship: The new normal. Public Policy \& Aging Report, 24(4), 141-147. doi: 10.1093/ppar/pru043

Jackson, M. (2014). The silver economy as a pathway for growth. Insights from the oecd-gcoa expert consultation 26 june 2014. Oxford: OECD

Jayawarna, D., Rouse, J., \& Kitching, J. (2011). Entrepreneur motivations and life course. International Small Business Journal, 31(1), 34-56. doi: 10.1177/0266242611401444

Kautonen, T. (2013). Senior entrepreneurship A background paper for the OECD Centre for Entrepreneurship, SMEs and Local Development. Turku: OECD.

Kautonen, T., Kibler, E., \& Minniti, M. (2017). Late-career entrepreneurship, income and quality of life. Journal of Business Venturing, 32(3), 318-333. doi: http://dx.doi.org/10.1016/j. jbusvent.2017.02.005

Kohli, M. (1986). The world we forgot: A historical review of the life course. In V. W. Marshall (Ed.), Later life. The social psychology of aging (Vol. 1986, pp. 271-303). Beverly Hills: Sage Publ.

Lewis, K., \& Walker, E. (2011). Self-employment: Policy panacea for an ageing population? Small enterprises research: the journal of SEAANZ, 18(2), 143-151.

Liang, J., Wang, H., \& Lazear, E. P. (2014). Demographics and entrepreneurship SIEPR Discussion Paper. Stanford, CA: Stanford Institute for Economic Policy Research, Stanford University.

Luck, F., Kraus, S., \& Bouncken, R. B. (2014). Senior entrepreneurship: Definitions and underlying theories. International Journal of Business Research, 14(3), 209-215. doi: 10.18374/IJBR-14-3.15

Minola, T., Criaco, G., \& Obschonka, M. (2016). Age, culture, and self-employment motivation Small Business Economics, 46(2), 187-213.

Organisation for Economic Co-operation and Development (OECD), \& European Union. (2017). The missing entrepreneurs 2017: Policies for inclusive entrepreneurship. In E. U. Organisation for Economic Co-operation and Development (OECD) (Ed.), The Missing Entrepreneurs. Paris: Organisation for Economic Co-operation and Development (OECD), European Union.

Organisation for Economic Co-operation and Development (OECD), \& The European Commission. (2015). Die fehlenden unternehmer 2014: Politiken für ein integrationsförderndes unternehmertum in europa. Luxembourg.

Schøtt, T., Rogoff, E. G., Herrington, M., \& Kew, P. (2017). Senior entrepreneurship. In G. E. R. A. (GERA) (Ed.), Special Topic Report. London: Babson College / Universidad del Desarrollo / Universiti Tun Abdul Razak / Tecnológico de Monterrey / London Business School.

Settersten, R. A. J., \& Mayer, K. U. (1997). The measurement of age, age structuring, and the life course. Annual Review of Sociology, 23, 233-261. doi: 10.1146/annurev.soc.23.1.233

Solinge, H. v. (2014). Who opts for self-employment after retirement? A longitudinal study in the netherlands. European Journal of Ageing, 11(3), 261-272.

Tornikoski, E. T., \& Kautonen, T. (2009). Enterprise as sunset career? Entrepreneurial intentions in the ageing population. International Journal of Entrepreneurship and Small Business, 8(2), 278-291. doi: 10.1504/IJESB.2009.024381

Weller, C. E., \& Wenger, J. B. (2017). Divergent fortunes: Income diversification, rising older entrepreneurship and falling younger entrepreneurship. 